\title{
2D NUMERIC SIMULATION OF SERRATED-CHIP FORMATION IN ORTHOGONAL CUTTING OF AISI316H STAINLESS STEEL
}

\author{
NUMERIČNA 2D SIMULACIJA NASTANKA NAZOBČANEGA \\ ODREZKA PRI PRAVOKOTNEM REZANJU AISI316H JEKLA
}

\author{
Arif Gök \\ Amasya University, Faculty of Technology, Department of Mechanical Engineering, 05100 Amasya, Turkey \\ arif.gok@amasya.edu.tr \\ Prejem rokopisa - received: 2017-04-06; sprejem za objavo - accepted for publication: 2017-05-30
}

doi:10.17222/mit.2017.038

\begin{abstract}
Low thermal conductivity, high strength, high ductility and high work-hardening tendency of austenitic stainless steels are the main factors that make their machinability difficult. This study investigates the influence of material modelling on the serrated-chip formation during the orthogonal cutting of the AISI316H stainless steel using finite-element simulations. Turning tests were carried out at three different cutting speeds and constant depth of cut and feed rate. Predictions were compared with the orthogonal-cutting tests and found to be in agreement.

Keywords: AISI 304 stainless steel, finite-element method, serrated-chip formation, machinability
\end{abstract}

Nizka toplotna prevodnost, visoka trdnost, velika duktilnost in sposobnost močnega utrjevanja so glavni vzroki za to, da se austenitno nerjavno jeklo težko mehansko obdeluje. V študiji so avtorji modelirali tvorbo nazobčanega ostružka med pravokotnim rezanjem AISI316H nerjavnega jekla. Za modeliranje so uporabili metodo končnih elementov (MKE). Preizkusi struženja so bili izvedeni pri treh različnih rezalnih hitrostih ter pri konstantni globini reza in pomikanja. Rezultate modeliranja so primerjali s praktičnimi preizkusi pravokotnega rezanja (struženja). Ugotovili so, da se praktični rezultati preizkusov dobro ujemajo z rezultati MKE-modeliranja.

Ključne besede: AISI 304 nerjavno jeklo, metoda končnih elementov, tvorba nazobčanih ostružkov, sposobnost strojnega obdelovanja

\section{INTRODUCTION}

Austenitic stainless steels, characterised by a high work-hardening rate and low thermal conductivity ${ }^{1}$, are used to fabricate chemical and food-processing equipment, as well as machinery parts requiring high corrosion resistance. ${ }^{2}$ They are generally regarded as more difficult to machine than carbon and low-alloy steels on account of their high strength, high work-hardening tendency and poor thermal conductivity. ${ }^{3,4}$ Problems such as poor surface finish and high tool wear are common. ${ }^{5}$ Work hardening is recognised to be responsible for the poor machinability of austenitic stainless steels. ${ }^{6}$ In addition, they bond very strongly to the cutting tool during cutting and when a chip is broken away, it may bring with it a fragment of the tool, particularly when cutting with cemented carbide tools. When machining this material, cutting-force variation is also much more obvious than in the case of machining unalloyed steel. ${ }^{1}$

Especially, in order to increase the productivity and tool life in the machining of the AISI304 and AISI316 series stainless steel, it is necessary to develop a reliable FE model for different cutting processes. To accurately analyse this process using numerical methods such as the finite-element analysis (FEA), the knowledge of the material constitutive behaviour under these severe loading conditions is a pre-requisite and hence correct work- material flow-stress data need to be used. In fact, the success and reliability of numerical models are heavily dependent upon the work-material-flow stress, friction parameters for the tool and work-material interfaces, the fracture criterion and thermal parameters. ${ }^{3,7-10}$

Many studies on the chip formation have been published by now. Titanium alloys are used in most of these studies. M. Bäker ${ }^{11}$ studied the influence of the material law determining the plastic flow on the chip formation of titanium alloys at high cutting speeds, while T. Özel et al. ${ }^{12}$ studied constitutive-material models to simulate the serrated-chip formation, including also other materials. In parallel with these investigations, M. Sima and T. Özel ${ }^{13}$ investigated the influence of constitutive-material models and elastic/viscoplastic finiteelement formulation on a serrated-chip formation for modelling the machining of the Ti-6Al-4V titanium alloy. R. Alvarez et al. ${ }^{14}$ analysed the effect of eight constitutive models on the saw-toothed chip formation in Ti6Al4V orthogonal cutting. In another study carried out by $\mathrm{G}$. Chen et al. ${ }^{15}$, a Johnson-Cook material model with an energy-based ductile-failure criterion was developed using a titanium-alloy (Ti-6Al-4V) high-speed machining FEA. D. Umbrello ${ }^{16}$ presented a finite-element analysis (FEA) of machining TiAl6V4 for both conventional and high-speed cutting regimes. Work to date has shown that little work has been carried on the determination of 
A. GÖK: 2D NUMERIC SIMULATION OF SERRATED-CHIP FORMATION IN ORTHOGONAL CUTTING OF AISI316H ...

the chip formation when machining AISI304 stainless steels. In a study carried out by J. Q. Xie et al. ${ }^{17}$, the theory of shear banding was included in the analysis of chip formation and chip instability. They used analytic and experimental methods to study these characteristics. This work aims to investigate the serrated-chip formation in the machining of the AISI304 stainless steel using finite-element simulations.

\section{EXPERIMENTAL PART}

\subsection{Turning process}

Turning processes were performed on a CNC turning lathe that has a capacity of $10 \mathrm{~kW}$ using AISI 1045 samples with dimensions of $\varnothing 50 \mathrm{~mm} \times 100 \mathrm{~mm}$. The rake angle was $0^{\circ}$ and the clearance angle was $5^{\circ}$. The turning processes were carried out using the turning parameters from Table 1. The cutting length for the turning processes was chosen to be $10 \mathrm{~mm}$.

Table 1: Turning parameters

\begin{tabular}{|c|c|}
\hline Parameters & Value \\
\hline Cutting speed $-V_{\mathrm{c}}(\mathrm{m} / \mathrm{min})$ & 100 \\
\hline Feed rate $-f\left(\mathrm{~min}^{-1}\right)$ & 0.1 \\
\hline Depth of cut $-a p(\mathrm{~mm})$ & 0.5 \\
\hline
\end{tabular}

\subsection{Numeric analysis}

In $2 \mathrm{D}$ numeric simulations, the cutting tool and the workpiece consist of a tetrahedral mesh. While the mesh structure of the workpiece consists of 1453 elements and 1547 nodes, the mesh structure of the cutting tool consists of 770 elements and 823 nodes. The mesh structure of the model of the workpiece and cutting tool

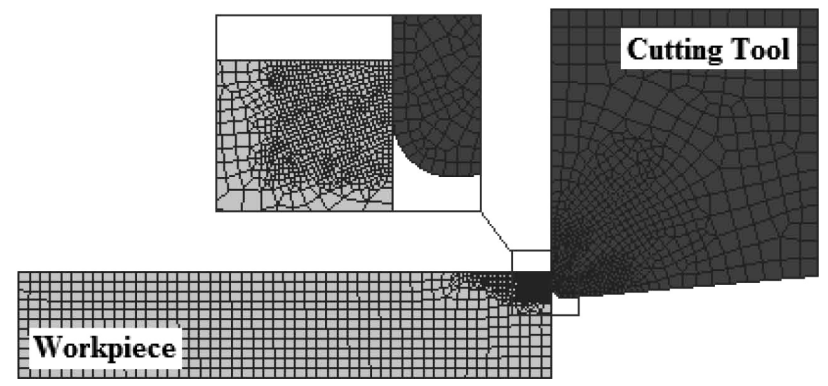

Figure 1: Mesh process

is given in Figure 1. However, the workpiece model was constrained by the lateral surfaces and lower surface. The contact algorithm for the interface of the cutting tool and workpiece was defined as the master and slave in the software. As the friction model for these two elements, the Coulomb model of friction was selected because it uses low cutting speeds. The Cockcroft-Latham fracture criterion was selected as the damage criterion. The Cockcroft-Latham criterion is given in Equation (1). According to the Cockcroft-Latham damage criterion, damage occurs when the accumulated stress state $\mathrm{D}$, over the plastic strain, reaches the critical damage value (Dcr). The Dcr was selected to be 90 for all the cutting simulations because it had the most suitable chip form. The friction coefficient for the simulation study was calculated to be 0.41 for the normal machining and 0.60 for the damage criterion. This coefficient of the friction between the tool and the chip in orthogonal cutting was calculated using Equations (2) and (3). ${ }^{18} F_{\mathrm{c}}$ and $F_{\mathrm{t}}$ forces were obtained experimentally; $F_{\mathrm{s}}, N_{\mathrm{s}}, F$ and $N$ forces depend on them and can be calculated from Figure 2.

$$
D=\int_{0}^{\bar{\varepsilon}_{f}} \sigma_{1} d \bar{\varepsilon}
$$

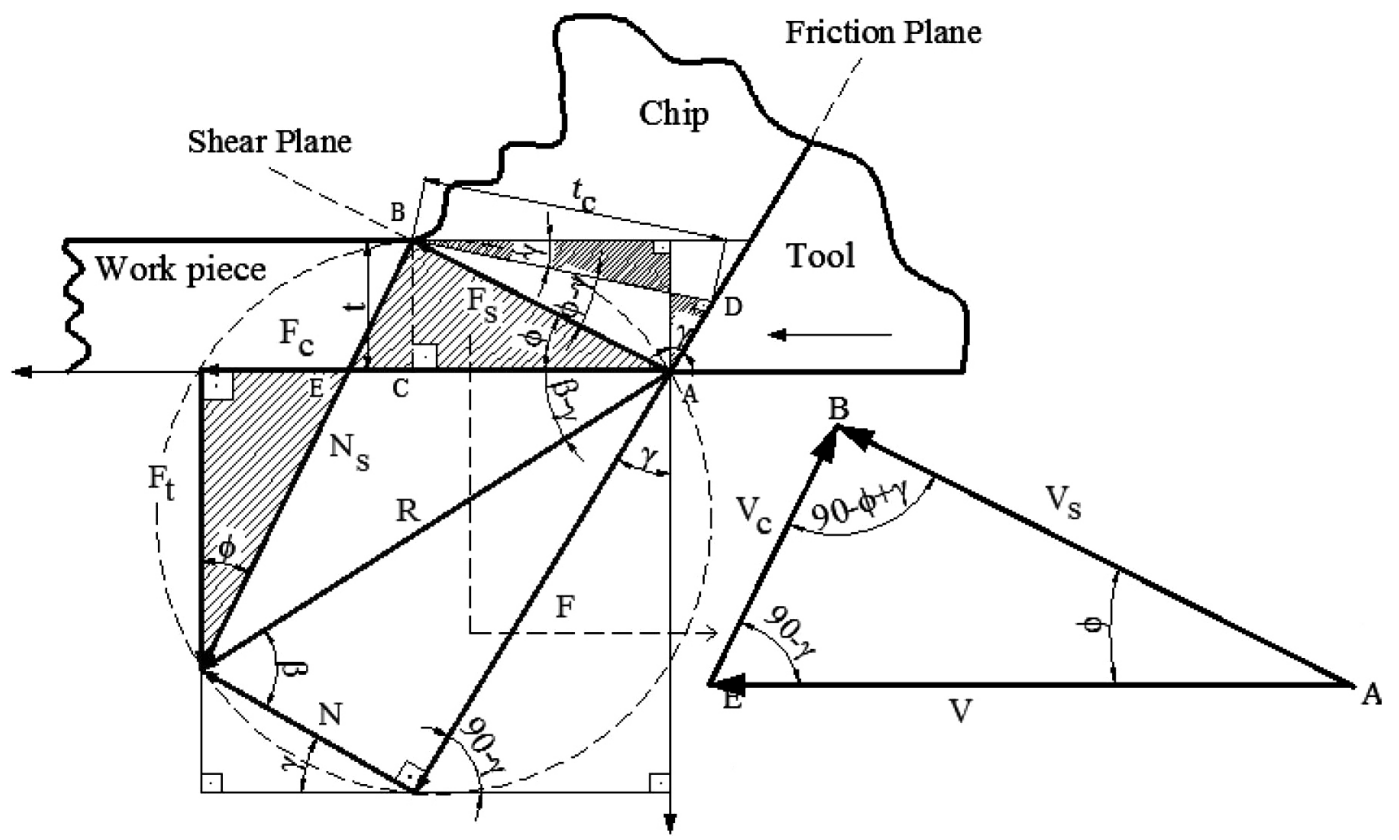

Figure 2: Two-dimensional (2D) force system in turning operations (Merchant's force circle) 


\section{MATERIALI IN TEHNOLOGIJE/MATERIALS AND TECHNOLOGY (1967-2017) - 50 LET/50 YEARS}

A. GÖK: 2D NUMERIC SIMULATION OF SERRATED-CHIP FORMATION IN ORTHOGONAL CUTTING OF AISI316H ...

$$
\begin{gathered}
\mu=\tan \beta=\frac{F}{N} \\
\mu=\frac{F_{\mathrm{t}}+F_{\mathrm{c}} \tan \gamma}{F_{\mathrm{c}}-F_{\mathrm{t}} \tan \gamma}
\end{gathered}
$$

\subsection{Material model}

While the workpiece was selected as AISI 316h, the cutting tool was selected to be tungsten carbide (WC). The mechanical and thermal properties of the WC and AISI $316 \mathrm{~h}$ are given in Table $2 .{ }^{19}$ The flow-stress curve of the workpiece-material model was taken from reference $^{19}$. The flow stress was defined as a function of the strain, strain rate and temperature as seen in Figure 3. The flow stress $(\bar{\sigma})$ in Equation (4) was selected to exhibit the true material behavior as a function of the effective plastic strain $(\bar{\varepsilon})$, effective strain rate $(\dot{\bar{\varepsilon}})$ and temperature $(T)$. The flow-stress curves are very important for high-temperature applications such as metal cutting.

$$
\bar{\sigma}=(\bar{\varepsilon}, \dot{\bar{\varepsilon}}, T)
$$

Table 2: Mechanical and thermal properties of the drill bit and bone materials $^{19}$

\begin{tabular}{|c|c|}
\hline \multicolumn{2}{|c|}{ Workpiece-material properties (AISI 316h316H) } \\
\hline Modulus of elasticity $(\mathrm{GPa})$ & $20{ }^{\circ} \mathrm{C}(210)$ \\
\hline Poisson's ratio & 0.3 \\
\hline $\begin{array}{c}\text { Thermal-expansion coefficient } \\
\left(10^{-6}{ }^{\circ} \mathrm{C}^{-1}\right)\end{array}$ & $93.33{ }^{\circ} \mathrm{C}\left(1.20 \times 10^{-5}\right)$ \\
\hline Thermal conductivity $(\mathrm{W} / \mathrm{mK})$ & $100{ }^{\circ} \mathrm{C}(17)$ \\
\hline Heat capacity $\left(\mathrm{N} / \mathrm{mm}^{2}{ }^{\circ} \mathrm{C}\right)$ & $93.33{ }^{\circ} \mathrm{C}(2.78)$ \\
\hline Emissivity & 0.7 \\
\hline Cutting-tool-material properties $(\mathrm{WC})$ \\
\hline Modulus of elasticity $(\mathrm{GPa})$ & 650 \\
\hline Poisson's ratio & 0.25 \\
\hline $\begin{array}{c}\text { Thermal-expansion coefficient } \\
\left(10^{-6}{ }^{\circ} \mathrm{C}^{-1}\right)\end{array}$ & 5 \\
\hline Thermal conductivity $(\mathrm{W} / \mathrm{mK})$ & 59 \\
\hline Heat capacity $\left(\mathrm{N} / \mathrm{s} / \mathrm{mm} /{ }^{\circ} \mathrm{C}\right)$ & 15 \\
\hline Emissivity & 0 \\
\hline
\end{tabular}

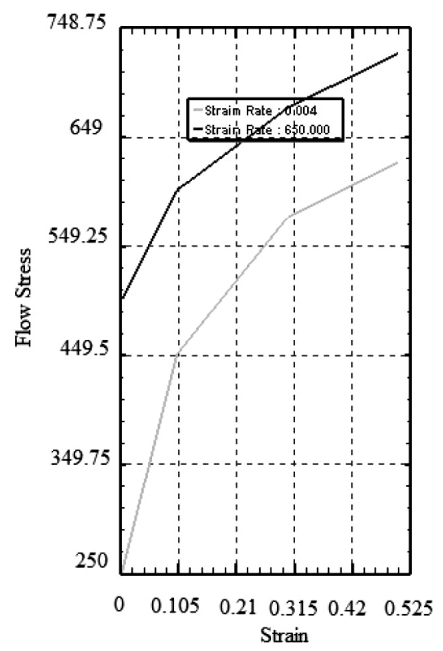

Figure 3: Flow-stress curves for the workpiece material ${ }^{19}$

\section{RESULTS}

At the end of the study, force variations occurred in the normal machining (NM) and the machining with damage criterion (MWDC) was very different, as seen in Figure 4. As seen in Table 3, while the MWDC deformed-chip thickness was lower than during the NM, the chip ratio and shear-angle values were higher during the MWDC than during the NM. Good agreement between experimental tests and FEM simulations was found for cutting forces and shear-angle values, as shown in Figures 5 and 6.
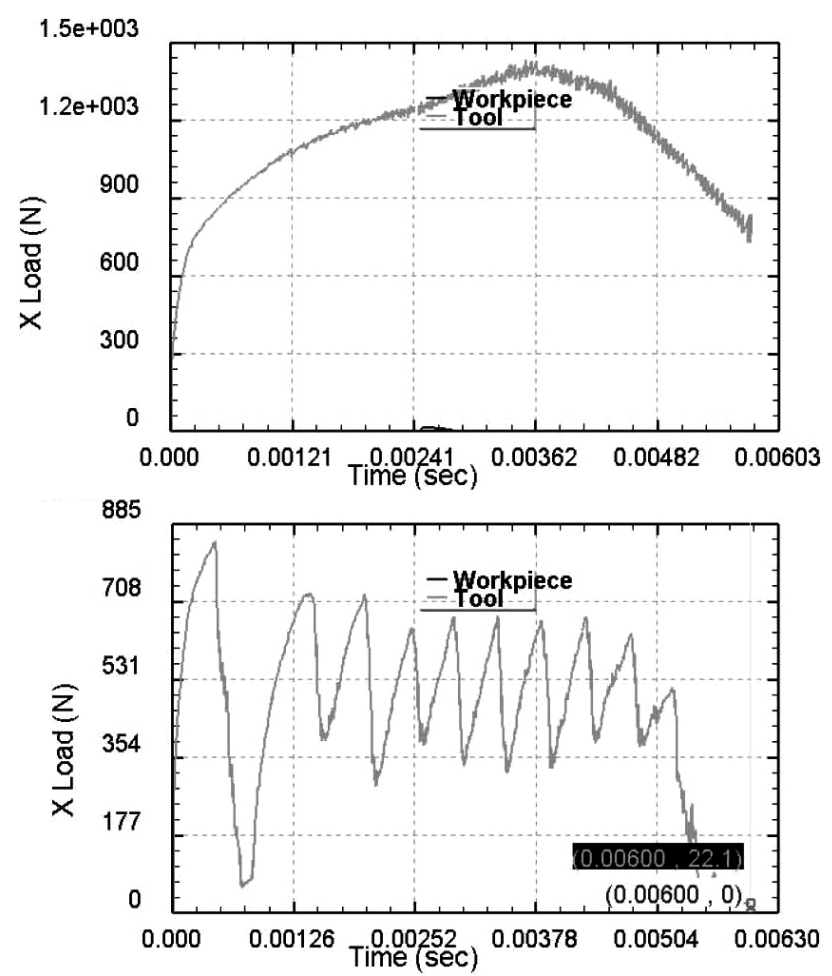

Figure 4: Force variations occurred during NM and MWDC

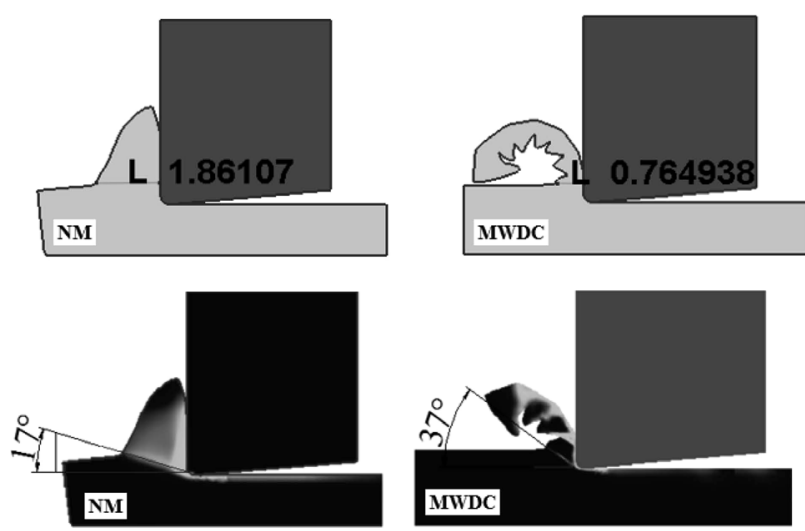

Figure 5: Deformed-chip thickness and shear angles for the NM and MWDC 
A. GÖK: 2D NUMERIC SIMULATION OF SERRATED-CHIP FORMATION IN ORTHOGONAL CUTTING OF AISI316H ...

Table 3: Comparison of NM and MWDC

\begin{tabular}{|c|c|c|c|c|c|c|}
\hline & $\begin{array}{c}\text { Cutting speed } \\
(\mathrm{m} / \mathrm{min})\end{array}$ & $\begin{array}{c}\text { Undeformed chip } \\
\text { thickness, } t(\mathrm{~mm})\end{array}$ & $\begin{array}{c}\text { Deformed chip } \\
\text { thickness, } t_{\mathrm{c}}(\mathrm{mm})\end{array}$ & Chip ratio, $r_{\mathrm{c}}$ & $\begin{array}{c}\text { Shear angle, } \phi \\
(\text { with Eg. 17) }\end{array}$ & $\begin{array}{c}\text { Shear angle, } \phi \\
(\text { FEM })\end{array}$ \\
\hline NM & 100 & 0.5 & 1.85 & 0.268 & 15 & 17 \\
\hline MWDC & 100 & 0.5 & 0.76 & 0.657 & 33.304 & 37 \\
\hline
\end{tabular}

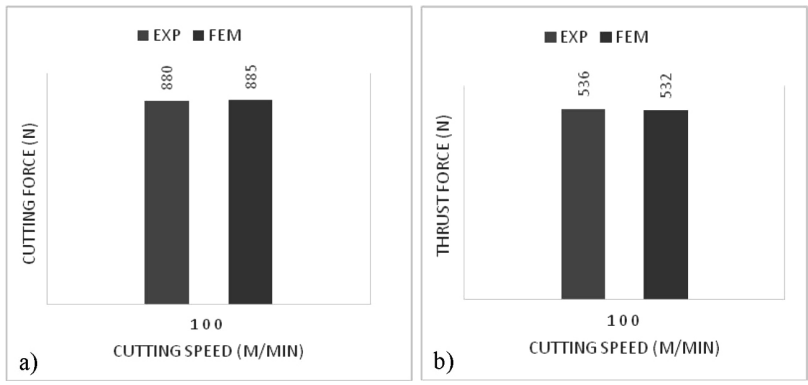

Figure 6: a) Cutting and b) thrust force for MWDC

\section{CONCLUSIONS}

In this study, a finite-element model was developed to see the effect of a serrated-chip formation in the machining of the AISI304 stainless steel using finite-element simulations. A computer-aided numerical simulation of the turning process was also performed using DEFORM - 2D software. It can be said that the 2D FEM model gives reasonable results compared to the experimental results in view of cutting forces, thrust force and shear angles. This proves the accuracy of the developed 2D FEM model, which can be used for this type of turning simulations.

\section{REFERENCES}

${ }^{1}$ S. Coromant, Modern metal cutting: a practical handbook, Sandvik Coromant Press, $1^{\text {st }}$ ed., 1994

${ }^{2}$ M. P. Groover, Fundamentals of Modern Manufacturing: Materials, Processes, and Systems, Prentice Hall, Wiley, 1996

${ }^{3}$ E. M. Trent, Metal Cutting, Elsevier Science, Butterworth-Heinemann, 2016

${ }^{4}$ J. Paro, H. Hänninen, V. Kauppinen, Tool wear and machinability of X5 CrMnN 1818 stainless steels, Journal of Materials Processing Technology, 119 (2001), 14-20, doi:10.1016/S0924-0136(01) 00877-9

${ }^{5}$ D. O'Sullivan, M. Cotterell, Machinability of austenitic stainless steel SS303, Journal of Materials Processing Technology, 124 (2002), 153-159, doi: 10.1016/S0924-0136(02)00197-8
${ }^{6}$ L. Jiang, ̊. Roos, P. Liu, The influence of austenite grain size and its distribution on chip deformation and tool life during machining of AISI 304L, Metallurgical and Materials Transactions A, 28 (1997), 2415-2422, doi: 10.1007/s11661-997-0198-z

${ }^{7}$ T. H. C. Childs, Material Property Needs in Modeling Metal Machining, Machining Science and Technology, 2 (1998), 303-316, doi:10.1080/10940349808945673

${ }^{8}$ M. C. Shaw, Metal Cutting Principles, Oxford University Press, 2005

${ }^{9}$ K. Maekawa, T. Obikawa, Y. Yamane, T. H. C. Childs, Metal Machining: Theory and Applications, Elsevier Science, 2013

${ }^{10}$ V. P. Astakhov, Metal Cutting Mechanics, Taylor \& Francis, 1998

${ }^{11} \mathrm{M}$. Bäker, The influence of plastic properties on chip formation, Computational Materials Science, 28 (2003), 556-562, doi:10.1016/ j.commatsci.2003.08.013

${ }^{12}$ T. Ozel, M. Sima, A. Srivastava, Finite element simulation of high speed machining Ti-6Al-4V alloy using modified material models, Transactions of the NAMRI/SME, 38 (2010), 49-56,

${ }^{13}$ M. Sima, T. Özel, Modified material constitutive models for serrated chip formation simulations and experimental validation in machining of titanium alloy Ti-6Al-4V, International Journal of Machine Tools and Manufacture, 50 (2010), 943-960, doi:10.1016/j.ijmachtools. 2010.08.004

${ }^{14}$ R. Alvarez, R. Domingo, M. A. Sebastian, The formation of saw toothed chip in a titanium alloy: influence of constitutive models, Journal of Mechanical Engineering, 57 (2011), 739-749, doi:10.5545/sv-jme.2011.106

${ }^{15}$ G. Chen, C. Ren, X. Yang, X. Jin, T. Guo, Finite element simulation of high-speed machining of titanium alloy (Ti-6Al-4V) based on ductile failure model, The International Journal of Advanced Manufacturing Technology, 56 (2011), 1027-1038, doi:10.1007/s00170011-3233-6

${ }^{16}$ D. Umbrello, Finite element simulation of conventional and high speed machining of Ti6Al4V alloy, Journal of Materials Processing Technology, 196 (2008), 79-87, doi:10.1016/j.jmatprotec.2007. 05.007

${ }^{17}$ J. Q. Xie, A. E. Bayoumi, H. M. Zbib, Analytical and experimental study of shear localization in chip formation in orthogonal machining, Journal of Materials Engineering and Performance, 4 (1995), 32-39, doi: 10.1007/bf02682702

${ }^{18}$ P. J. Arrazola, T. Özel, Investigations on the effects of friction modeling in finite element simulation of machining, International Journal of Mechanical Sciences, 52 (2010), 31-42, doi:10.1016/ j.ijmecsci.2009.10.001

${ }^{19}$ DEFORM-3D Material Library, http://home.zcu.cz/ sbenesov/ Deform2Dlabs.pdf, 12.04.2017 